Sultan Qaboos University Journal of Arts \& Social Sciences
جامعة السلطان قابوس

مجلة الآداب والعلوم الاجتمأعية

\title{
The Use of Remote Sensing and GIS to Study Land Use Changes in Barka Wilaya, Oman
}

\footnotetext{
Eyad. H. R. Fadda

Associate Professor

Department of Geography,

Faculty of Arts and Social

Sciences,

Sultan Qaboos University,

efadda@squ.edu.om
}

\footnotetext{
Fatemah Al Shebli

Department of Geography,

Faculty of Arts and Social

Sciences,

Sultan Qaboos University,
}

\footnotetext{
Ayshah Al Kabi

Department of Geography,

Faculty of Arts and Social

Sciences,

Sultan Qaboos University,
} 


\section{The Use of Remote Sensing and GIS to Study Land Use Changes in Barka Wilaya, Oman}

Fadda, Al Shebli, Al Kabi

\section{Abstract}

Many studies house indicated the increase of the proportion of urban areas over the arable land in many provinces of the Sultanate of Oman. This came as a result of urban growth and development processes taking place since the era of the Renaissance which started in 1970. Consequently, spatial variation in land use is an important issue to be taken into consideration, because lands are being converted to be less productive, due to the lack of raw soil, vegetation, and water as a result of human exploitation of the limited resources in different ways, in addition to the natural factors of droughts and floods and all that will eventually lead to land degradation. Barka province (wilayat) in al Batinah Governorate is one of the provinces, which has been affected by land cover/land use changes due to several reasons. Therefore, this study will focus on the determination of land use changes, whether commercial or residential that have been occurred in the province, in addition to the loss of agricultural areas and fertile land during the period from 1987 to 2015. Remote sensing and geographic information system (GIS) were utilized in order to delineate and to determine the cause of shrinking in the arable land and fertile land. Satellite images were used to detect the change in land use/land cover by applying selective digital image processing techniques such as supervised classification and change detection. Thematic maps were prepared using GIS software with attribute data about the land uses in the study area, which highlights and show the impact of urban growth on land degradation.

Keywords - urban growth, Spatial variation, land uses changes, land degradation.

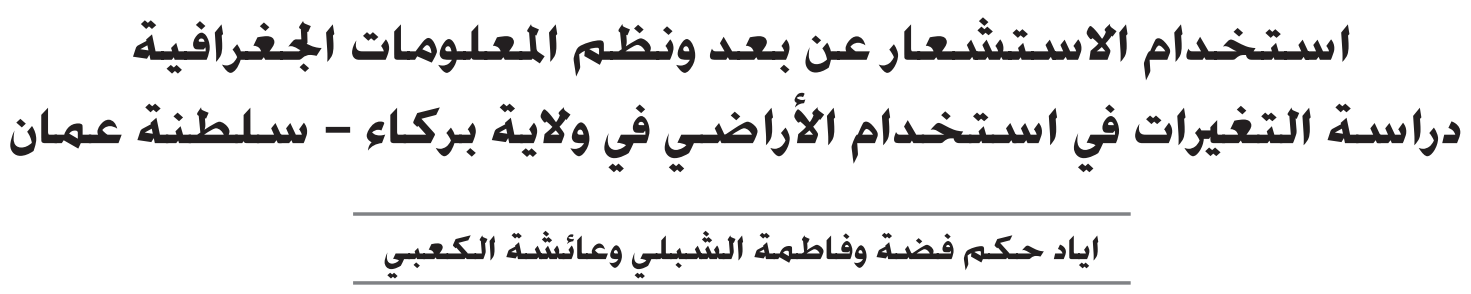

الملنخص:

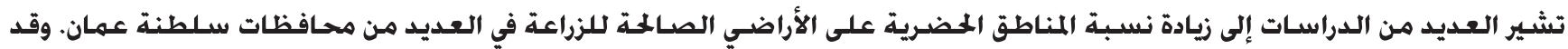

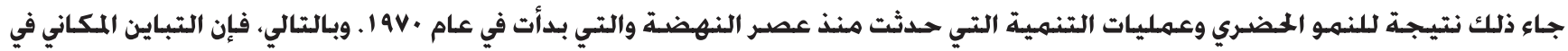

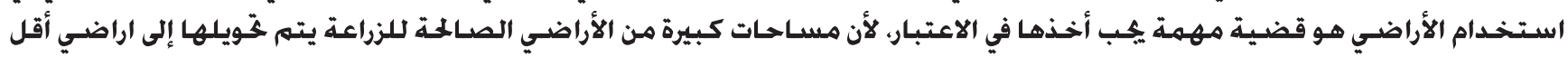

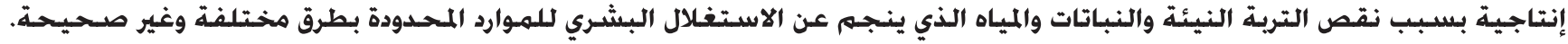

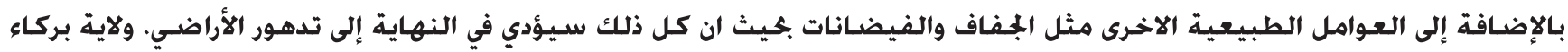

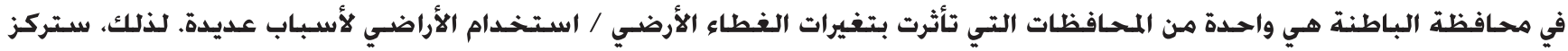

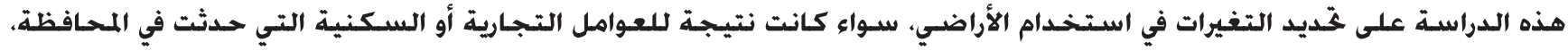

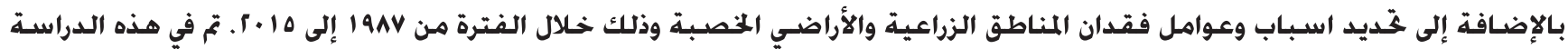

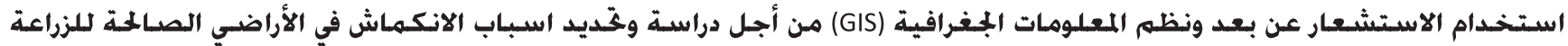

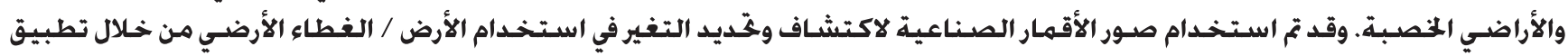

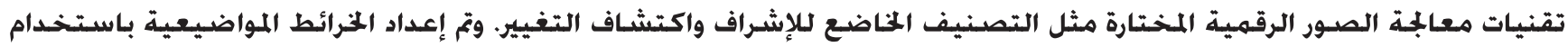

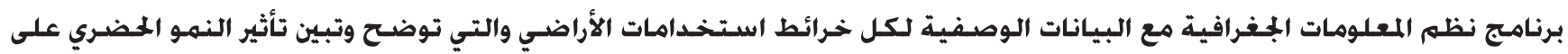
الاراضـي الزراعية ومن ثم تدهور تلك الأراضـي.

الكسلمـات المفتاحية : النمـو الحـضـري، التغير المكاني، استخـدامـات الأرض للتغيرات، تدهور الأراضـي. 


\section{1- INTRODUCTION}

\section{1-1 Study area:}

The study area is located on the coastline of Oman Sea, and it is surrounded from the north by Oman Sea, from the east by Wilayat Al Seeb, from the west by Wilayat Al Mosanaa, and from the south by Wilayat Wadi Al Meawal. Wilayat Barka (Barka Province) is located between $\left(57^{\circ} 33^{\prime} 13^{\prime \prime}\right)$ north and $\left(23^{\circ} 42^{\prime}\right.$ $\left.33^{\prime \prime}\right)$ south. The estimated area of Barka is around (840 square kilometers) and population $(71,000)$ distributed to more than 52 villages.

\section{1-2 Objectives}

The objectives of this study are to study define the natural and human characteristics of Wilayat Barka, recognize the condition of the farmed area by detecting the changes and the extent of land degradation in the area.

The factors that are causing the degradation of the land will be analyzed and appropriate solutions will be proposed to reduce the land degradation in the area. Another objective for this study is to highlight the role of GIS and remote sensing systems in identifying land degradation in the area.

\section{1-3 Problem of the Study}

The main goal of the study is to specify land degradation in Wilayat Barka, which happened due to the transformation of arable farmland into barren land. The main factors that caused this transformation can be categorized into natural and human factors. This study provides an analysis and interpretation of those factors, by classifying and producing the necessary maps along with recommendations to reduce and avoid the negative effects.

\section{1-4 Methodology}

The study adopted the descriptive and analytical methods by reviewing previous studies in order to determine the nature of degradation in Wilayat Barka. The data network of the Sultanate of Oman (Oman data) was also used. The study implemented remotely sensed data using multi dates satellite images (Landsat, 1987) and (Ikonoos, 2015). Normal false-color combination of the satellite images was used in order to locate the agricultural areas and urban areas in order to compare development, growth, and change. The variation in the vegetation has been studied through the Normalized Difference Vegetation Index (NDVI) from the year 1987 to the year 2015. GIS software was used to produce the final

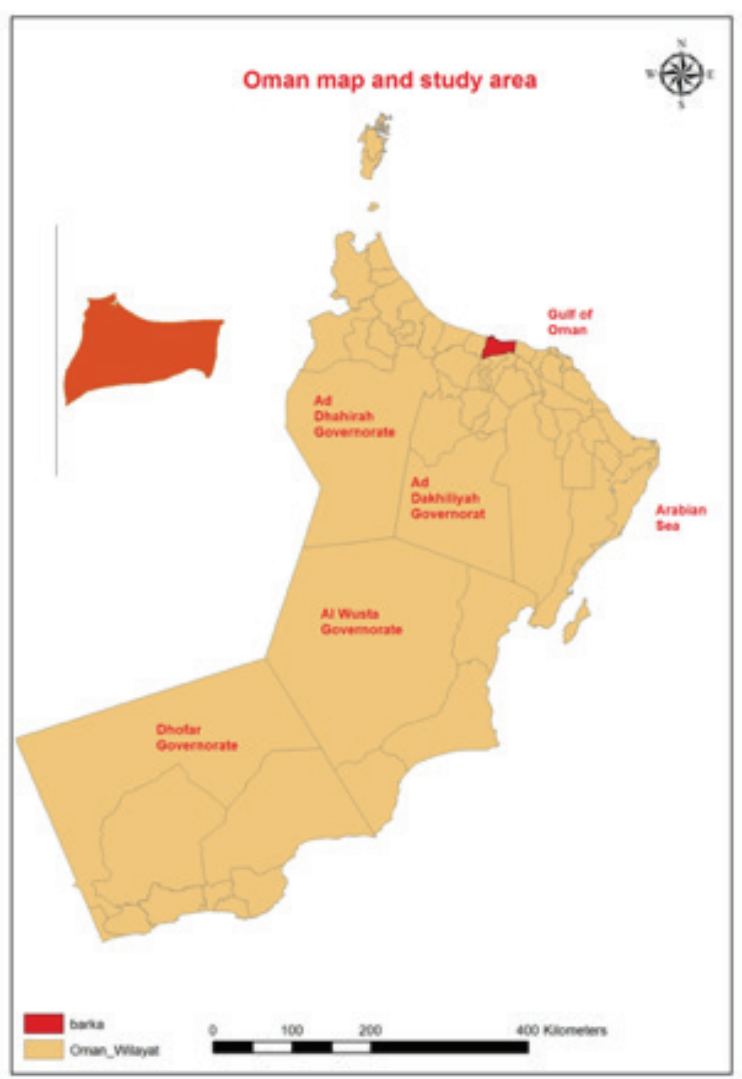

Figure 1. The location of the Study area.

thematic maps.

\section{1-5 Previous Studies}

Previous studies have focused on the changes in the Sultanate of Oman as a whole in many aspects including land cover/ land use in which they confirmed that there is an increase in the proportion of urban areas and shrinking in agricultural areas as a result of urban growth and development processes taking place in the Sultanate of Oman since the dawn of the era of the Renaissance in 1970. (Al-Awadi, 2008), (Al raisi, 2013), (Saadi, 2000). Some other studies have indicated that there is a natural risk to the land in general. (Al-Awadi, 2008), (Al Hatroshi, 2015).

\section{2- Land/Vegetation Degradation}

According to Dubovyk "Land degradation (LD) is one of the biggest global challenges for people's livelihoods and environment. Remote Sensing plays an unprecedented role in LD mapping, assessment and monitoring at multiple spatial and temporal scales. Regardless of a big potential of Remote Sensing to support LD studies, there are still quite a few challenges that impede its successful application." (Dubovyk, 2017). In the Nairobi conference in 1977, the participants agreed to consider that vegetation 
decay is one of the important indicators of land degradation. Plants prevailing high sensitivity to drought conditions in dry and semi-dry and marginal lands are the most important indicators. It can measure decaying vegetation by measuring the number of field observations:

- The negative change in vegetation in terms of distribution, diversity, and density in the wet and dry seasons.

- Lands shrinkage compared with a marked increase in agricultural and urban spaces.

- The high sensitivity of plants, especially in the dry season.

- The observed increase in the prevalence of plants is palatable for grazing.

- The disappearance of rover grazing systems.

- Natural animal mass decreased as a result of decreasing shelter

\section{2-1 Decaying vegetation in the Wilayat Barka}

Previous studies show that the presence of decaying indicators of vegetation in Barka is due to the emergence of two main factors, natural and human. Natural factors include salinization, desertification, drought, soil type, climate and agricultural pests. Human factors include the farmers abandoning their agricultural land and bringing non-eligible expats, overuse of pesticides, water depletion, overgrazing, transferring properties of agricultural land to residential and commercial land, lack of interest of young people in the profession of agriculture. This is illustrated by the declining tracts of agricultural crops and declining productivity yield per acre. In addition, to the development policies that led to the abandonment of the population to the agricultural activity.

\section{3- Remote sensing}

Remote sensing in the field of agriculture is considered to be one of the most important techniques, that can be applied effectively to detect the rapid changing in vegetation and land use change. Remote sensing enables monitoring of agricultural land changes and following its development and management by gathering information on land use as well as soil classification and other issues such as pollution, salinity, drought, erosion.

Accordingly, the use of remote sensing techniques in this study was effective and successful in terms of the data recorded by spatial sensors; that enabled, to identify areas on satellite images and to identify

changes that have occurred.

Figures. 2 and 3 are the satellite images (Landsat _1987) and (Ikonoos_2015) respectively. The figures illustrate different earth features and the changes that have occurred in the study area over 28 years (from 1987 to 2015). Figure 4 and 5 show the difference in the vegetation through the Normalized Difference Vegetation Index (NDVI) from the year 1987 to the year 2015. The occurrence of coastal alluvial fans across and parallel to the highway in 2015 have become significant and indicated the decrease in agricultural spaces and quality.

\section{4-Geographic information system}

Geographic information system (GIS) is a computerbased system that works on the collection, maintenance, storage, analysis, output and distribution of spatial data and information. Using the modern techniques of GIS can produce maps that show natural resources of a particular area, such as water, mineral and other raw materials.

The maps produced by GIS are considered significant because they are flexible in terms of updating, correction, development, etc... The process begins by building databases by digitizing available paper maps and using satellite imagery after connecting the geographical features to their real positions on the earth surface. The final product of the maps displayed to clarify the information by specific symbols on the map. For this purpose, GIS software has been used to analyze and to produce several maps showing the spatial distribution of the deferent spatial features in the study area. These maps were saved as spatial layers in GIS environment for the following features; wadies, urban areas, vegetation covers, populated areas, road networks, and other features as shown in

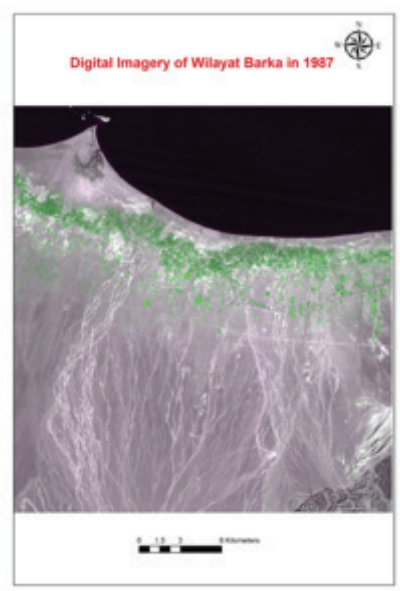

Figure 2. satellite image (Landsat_1987) Barka in 1987

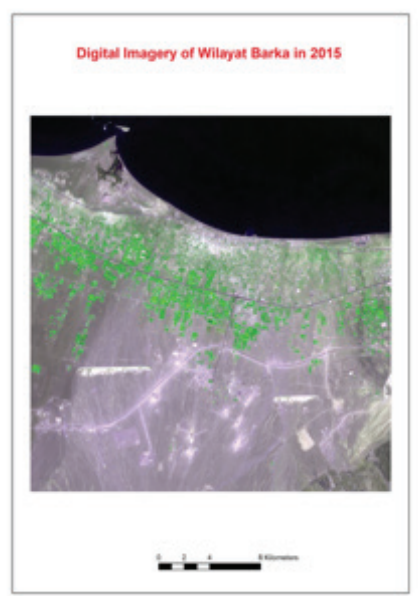

Figure 3. satellite image (Ikonoos_2015) Barka in 2015 
figures. 6 to 10 .

\section{5-Significant Research Findings}

- The most significant findings in this research are summarized in the following:

- Across Al Batinah plain and along the main road that connects Sultanate of Oman with the United Arab Emirates; where the most fertile agricultural and pastoral land, there are a lot of villages covering both sides of the road. Land owners were encouraged to sell their lands for the purposes of housing, industry and business centers.

- Also, large fertile land was changed to be used by governmental and public institutions and for public services and residential areas to contain rapid population growth.

- In the GIS environment a digital spatial information system (DSIS) has been produced for all spatial and attribute information in the form of GIS layers; those have been produced and used in this study for Barka Provence, such as satellite images and satellite maps of roads and valleys, population and areas of farming systems as shown in Figure 11.

\section{6- Results}

The visual interpretation of multi-date satellite imagery proves and clarify that the study area is experiencing urban growth that has led to shrinking in farmland. Natural and human factors had a great impact on land degradation through salinization of water and soil. The fluctuation of rainfall and long periods of drought had also contributed a great deal. The high rate of population growth and the high rate of urbanization also played a remarkable shrinkage in agricultural areas. The cutting of trees and expansion of the asphalt road networks and its crossing of the

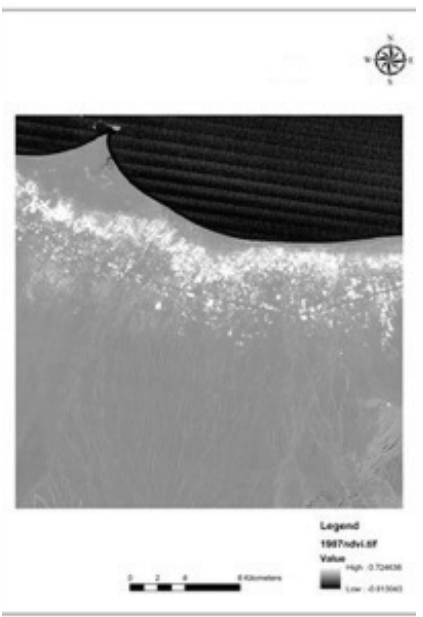

Figure 4. Distribution of vegetation in 1978, the Normalized Difference Vegetation Index (NDVI)

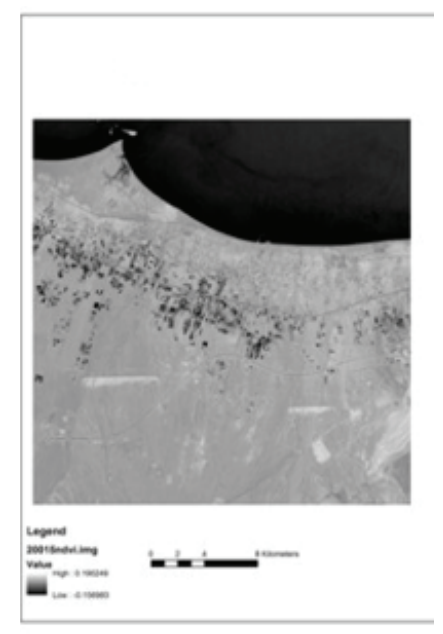

Figure 5. Distribution of vegetation in 2015, the Normalized Difference Vegetation Index (NDVI)

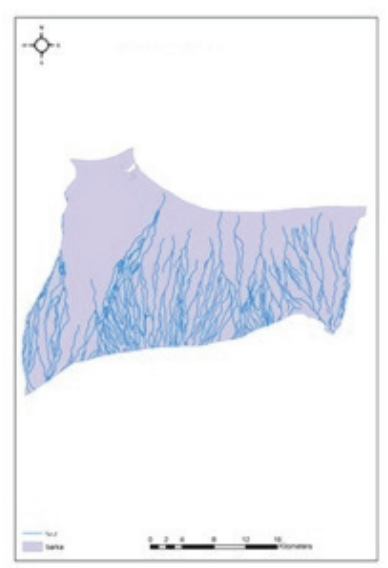

Figure 7. Map for Urban areas in Barka

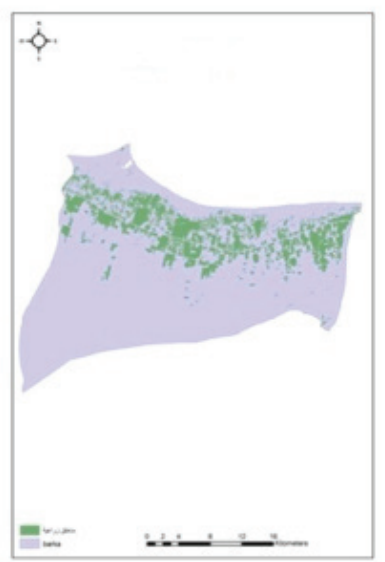

Figure 8. Map for vegetation covers in Barka

Wadis were depicted also by the aid of satellite images. The production of GIS layers and databases for all spatial information of the study area, such as satellite images and satellite maps of roads and wadies, the populated area can be used as a digital spatial information system (DSIS). The study recommends the development of housing policies that support the vertical extension of the housing, especially in the urban center of Barka instead of horizontal sprawl and crawl on farmland. And the need for environmental control and coordinate efforts among institutions to combat the deterioration of agricultural land in the Barka Province.

\section{Acknowledgment}

The authors would like to thank the Department of Geography, Faculty of Arts and Social Sciences, Sultan Qaboos University for their support and encouragement to carry out this research.

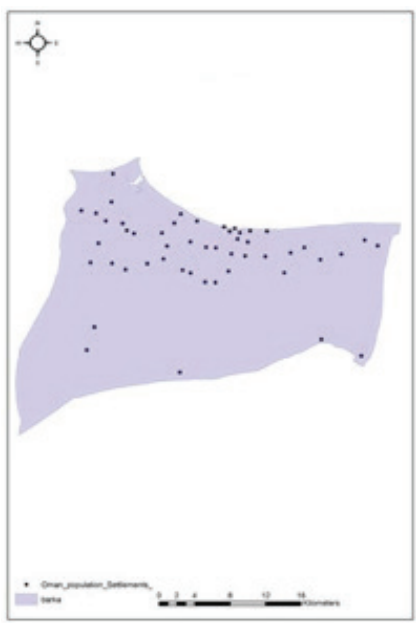

Figure 9. Map for populations in Barka

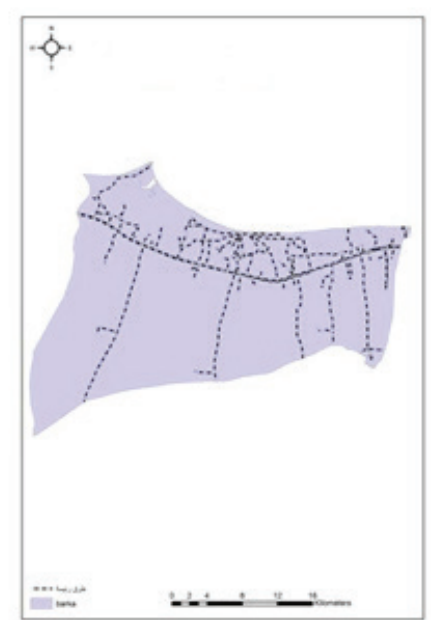

Figure 9. Map for populations in Barka 


\section{Reference}

Al-Awadhi, T (2008). Analysis, assessment, and modeling of the Urban Growth in Greater Muscat, Sultanate of Oman, Using Geographical Information Systems \& Remote Sensing. Egypt. J. Remote Sensing \& Space Science, 1(1), 3-22.

Al-Hatrushi, S \& and Sherief Y. (2015). Assessment of the potential impacts of sea level rise on the Coastal Plain of Al Batinah, Sultanate of Oman. Arabian Geographical Journal, 66(1), 1-22.

Al Raisi, Z (2013). Study of changes in land use in Wilayat Al Seeb. Sultan Qaboos University Press.

Brueckner, J (2001). Urban Sprawl: Lessons from Urban Economics. Brookings-Wharton Urban Affairs Journal, 1(3), 65-97.

Catanese, A.J. and Snyder, J.C. (1988). Urban Planning, second ed, McGraw press.

Hanmer, T.J. (1985). The Growth of Cities, Watts press.

Jensen, J. R. (1986). Introductory digital image processing: a remote sensing perspective, Englewood Cliffs, Prentice-Hall.

Lillesand, T. M. and Kiefer, R.W. (2007). Remote sensing and image interpretation, New York: Chichester: John Wiley \& Sons, Inc.

Mouat D. A., Mahin G. G., \& Lancaster J. (1993). Remote sensing techniques in the analysis of change detection, Geocarto International, 8(2), 39-50.

Olena D. (2017). The role of Remote Sensing in land degradation assessments: opportunities and challenges. European Journal of Remote Sensing, 50(1), 601,

Saadi, S. (2000). Terrain and its impact on economic activity in the Batinah region in Oman. Sultan Qaboos University press. 